University of Michigan Law School

University of Michigan Law School Scholarship Repository

Law \& Economics Working Papers

$1-1-2014$

\title{
The Parallel March of the Ginis: How Does Taxation Relate to Inequality and What Can Be Done About it?
}

\author{
Reuven S. Avi-Yonah \\ University of Michigan Law School, aviyonah@umich.edu
}

Follow this and additional works at: https://repository.law.umich.edu/law_econ_current

Part of the Law and Economics Commons, Law and Society Commons, and the Tax Law Commons

\section{Working Paper Citation}

Avi-Yonah, Reuven S., "The Parallel March of the Ginis: How Does Taxation Relate to Inequality and What Can Be Done About it?" (2014). Law \& Economics Working Papers. 96.

https://repository.law.umich.edu/law_econ_current/96

This Article is brought to you for free and open access by University of Michigan Law School Scholarship Repository. It has been accepted for inclusion in Law \& Economics Working Papers by an authorized administrator of University of Michigan Law School Scholarship Repository. For more information, please contact mlaw.repository@umich.edu. 
THE PARALLEL MARCH OF THE GINIS:

HOW DOES TAXATION RELATE TO INEQUALITY

AND WHAT CAN BE DONE ABOUT IT?

Reuven S. Avi-Yonah ${ }^{1}$

\begin{abstract}
The United States currently has one of the highest levels of inequality among industrialized economies. In addition, numerous scholars have shown that social mobility in the United States is significantly lower than it was in the period between 1945 and 1970, when inequality was also declining. The combination of these trends is dangerous because it risks transforming the US into a society where small elites capture most of the gains, a pattern in which growth cannot be sustained over time (Acemoglu and Robinson 2012, Zingales 2012). The level of inequality in the US after taxes and transfers are taken into account is much lower, but it is still higher than in most OECD countries and the trend is still for inequality to increase. This paper explores how the US tax system can be used to counter these trends and concludes that the key is not to increase taxes on the rich (although some reforms in this direction can be adopted), but instead to adequately fund and even strengthen the social safety net. The only way to do this in the medium to longer term is to adopt a broad-based federal consumption tax.
\end{abstract}

\footnotetext{
${ }^{1}$ Irwin I. Cohn Professor of Law, the University of Michigan, 625 S. State St., Ann Arbor, MI 48109.
} 
The United States currently has one of the highest levels of inequality among the members of the Organization for Economic Cooperation and Development (OECD), as measured by the Gini coefficient before taxes and transfers. The US Gini coefficient before taxes is 0.49 , measured on a scale in which 100 is perfect inequality (one person has all the income) and 0 is perfect equality. Table 1 shows that the US Gini is higher than most of the other members of the OECD, and it is also higher than many developing countries (e.g., India).

Insert Table 1

This level of inequality would not matter if social mobility in the US were high, because in that case every US child could achieve the "American dream." However, a recent OECD study pointed out that "[m]obility in earnings across pairs of fathers and sons is particularly low in France, Italy, the United Kingdom and the United States, while mobility is higher in the Nordic countries, Australia and Canada." (OECD 2010, p. 183). The US ranked third from the bottom among the twelve countries studied. The main reason was that the US ranked first in the influence of parental background on student achievement in secondary education (OECD 2010, Fig. 5.3). In general, the OECD found that intergenerational social mobility tends to be lower in more unequal societies (OECD 2010, Fig. 5.10).

Numerous scholars have shown that social mobility in the United States is significantly lower now than it was in the period between 1945 and 1970, when inequality was also declining (Frank, 2014). The combination of these trends is dangerous because it risks transforming the US into a society where small elites capture most of the gains, a pattern in which growth cannot be sustained over time (Acemoglu and Robinson 2012, Zingales 2012). As Acemoglu and Robinson demonstrate, societies with "extractive" institutions tend to stagnate in comparison with societies with "inclusive" institutions. Moreover, as Zingales points out, the US used to be more inclusive but is now becoming more extractive as established elites use their financial resources to lobby for and capture economic rents. A classic example is the tax treatment of the labor income of hedge fund managers as capital gains taxed at half the rate.

How does taxation enter into the picture? The level of inequality in the US after taxes and transfers are taken into account is significantly lower, although it is still higher than in most OECD countries and the trend is still for inequality to increase:

\section{Insert Table 2}

The striking fact visible in the data above is that the trend line is the same from 1984 to 2008 , i.e., the Gini coefficient moves more or less in parallel before taxes and transfers and after taxes and transfers are taken into account. This pattern is surprising because (a) the US relies heavily on individual income taxes, and those taxes are very progressive; (b) the top marginal tax rate and the tax rates on capital gains and dividends changed numerous times during the relevant period, so if progressive income taxation reduces inequality, one would expect the before and after tax Ginis to diverge rather than march in parallel. 
Compared to other countries, the US relied heavily on individual income taxes throughout the relevant period, and those taxes are quite progressive. In 2001, the top $1 \%$ of the US population by adjusted gross income (AGI) paid $33.89 \%$ of federal personal income tax, and the top 5\% paid $53.25 \%$ (by comparison, the bottom $50 \%$ of the AGI distribution paid less than $4 \%$ of total income taxes collected). This is a significant increase from 1994 , when the top $1 \%$ of taxpayers only paid $28.7 \%$ of federal personal income tax. In 2004, even after President Bush's tax cuts, the top 1\% still paid $32.3 \%$ of federal individual income taxes and the top $5 \%$ paid $53.7 \%$. In 2008 , the top quintile paid $94.6 \%$ of federal individual income taxes, the highest percentage since 1979 (IRS 2013).

Given this level of progressivity, it is striking that the US Gini after taxes increased steadily during the entire period from 1983 to 2008, in parallel to the before tax GIni. Moreover, if one examines the movements of the top individual tax rate in that period, one can see quite dramatic fluctuations: It went from $50 \%$ in 1983 down to $28 \%$ in 1986 , then gradually up to $39.6 \%$ in 1993 , then down to $35 \%$ in 2001 , and back to $39.6 \%$ in 2012. The capital gains rate went up from $20 \%$ in 1983 to $28 \%$ in 1986 , then down to $20 \%$ in 1997 , then down again to $15 \%$ in 2003 , and up to $20 \%$ in 2012 . None of these changes seem to have made an impact on the after-tax Gini.

A more detailed examination of the data, however, suggests the answer to this puzzle. Table 3 shows the Congressional Budget Office (CBO, 2011) estimate of the contribution of taxes and transfers to the reduction in the Gini coefficient:

\section{Insert Table 3}

The table indicates that (a) there has been some decline in the degree to which taxes and transfers reduce the Gini from 1979 to 2007, but the system as a whole is still quite progressive, reducing the Gini by about 17\%; (b) both taxes and transfers contribute to the reduction, but transfers contribute more than taxes; (c) after 1986, despite numerous changes in the tax rates, the contribution of taxes to decreasing inequality is essentially flat, while all the fluctuation is due to changes in transfers (since the overall line tracks the transfers line).

These data suggest that the answer to increasing inequality is not more progressive income taxation. High rates of income taxation raise familiar problems such as increased tax avoidance, choosing leisure over labor, and potentially emigrating to low-tax jurisdictions (Avi-Yonah, 2012). While the US top individual tax rate is lower than that in some OECD countries, those countries typically have lower rates on capital income, which is highly concentrated at the top of the income distribution. This comparison suggests that in a globalized world, the US does not have a lot of capacity to raise the tax rate on the rich further; certainly the $70 \%$ top marginal rate of 1980 , or the $94 \%$ tax rate of the 1950 s, appear unlikely to return when the rich can easily move to other countries, give up their US citizenship, and enjoy much lower rates.

Overall, the US tax and transfer system has a very significant impact on inequality: As Table 2 indicates, it reduces the US Gini by about 10 points, which is more than the difference between the pre-tax Gini of the US and Sweden. So if it is not the progressive tax system that does the work, what does? The answer must be the much-maligned "entitlements": Social Security, Medicare and Medicaid. These programs 
are very progressive because while only Medicaid is means tested, their benefits are more important to the poor, while the funding comes from progressive taxation of labor income (although in the case of Social Security the funding could be made more progressive by eliminating the income cap).

Thus, one key to reducing inequality in the US is to bolster the social safety net. We should at least maintain current benefits and possibly increase them. In particular, Social Security should be strengthened since most baby boomers do not have nearly enough saved for retirement (and many have seen their savings decimated by the Great Recession). The Affordable Care Act has strengthened health care, but it will probably require more funding to support insurance for persons with pre-existing conditions and the poor if not enough young, healthy people sign up for the exchanges.

Moreover, strengthening the social safety net is important to sustaining growth. Open economies tend to have stronger safety nets, because the gains from having an open economy tend to impose risk on the people who lose from globalization, so that a strong safety net is in a democracy a precondition to obtaining widespread political support for openness, which in turn produces growth (Avi-Yonah, 2000). Thus, if we want to avoid the pattern that led to the end of the first era of globalization a hundred years ago, we need to maintain a strong safety net lest the US public vote for protectionism, decreased immigration, and less tolerance for the "creative destruction" of technologically inspired growth. How can the US safety net be financially sustained in the long run? The answer cannot be more deficit financing, for two reasons. First, this just means passing the buck to our children, which seems both unfair and risky: As the population ages the number of working age adults to seniors (the dependency ratio) will decline in the US as it already did elsewhere, unless we are willing to accept much more immigration, which carries its own risks (Collier, 2013). Second, much of the US Treasury debt is held by China, and that is exactly how the UK lost its position as a great power after World War II: Too much of its debt was held by the US, which was able to dictate terms.

Nor is the answer raising the income tax. There are not enough rich people to support the safety net, and as stated above the rich can adjust to higher rate by avoiding taxes, working less, or moving. Nor would it be wise to increase the income tax on corporations (they can move even more easily than the rich) or on the middle class, since they already carry heavy burdens and cannot afford to bear the entire load (Warren and Tyagi, 2007).

Another reason why the social safety net cannot be financed by increased taxes on labor (either income or payroll taxes) is inter-generational equity. The benefits of Social Security and Medicare flow to the old, while income and payroll taxes are borne by the young. In addition to the dependency ratio concerns raised above, it seems unfair (and will certainly appear so to many young voters) to transfer so much from the young to the old.

The only solution is to enact a broad federal consumption tax, i.e., a Value Added Tax (VAT). This proposal has been developed in detail elsewhere (Avi-Yonah, 2010). For present purposes, a VAT has an important advantage: Unlike income and payroll taxes, consumption taxes do not discourage work, and because the old as well as the young consume, they are borne in significant part by the principal 
beneficiaries of the social safety net. In addition, VATs are used in over 150 countries and have a demonstrated capacity to raise revenues even with far weaker tax administrations than the IRS.

The VAT is regressive, and while there are ways to mitigate regressivity within the VAT like exempting basic living necessities, such exemptions subsidize well-off consumers and make the tax needlessly complicated. If VAT revenues are segregated and used to fund Social Security, Medicare and Medicaid, the inherent progressivity of those programs mitigates the regressivity of the underlying tax.

Moreover, in addition to bolstering the safety net, a VAT can be used to fund opportunity programs for the next generation, like universal pre-K, which will contribute directly to improving social mobility. The biggest obstacle to enhancing social mobility in the US is that by the time children start formal schooling many of them lag so far behind their peers that even good public schools cannot enable them to get to college, which is the essential gateway to the middle class in a technology dominated economy.

Ultimately, the challenge in enacting a VAT is political. Rep. Ullman, who was Chair of Ways and Means in the 1970s, supposedly was defeated after proposing one. But this story is a myth, and good politicians like John Howard of Australia have managed to build a broad legislative coalition to enact a VAT even after promising not to do so, and to win re-election decisively. A VAT serves the right's need for fiscal balance and the left's need to expand social outlays, so that it represents the ultimate "grand bargain" in American politics. It is a fair and sensible way to address the inequality that threatens our future. 
Table 1

Gini Index - Income Disparity since World War II

where 0 is perfect equality, and 100 is perfect inequality (i.e., one person has all the income)

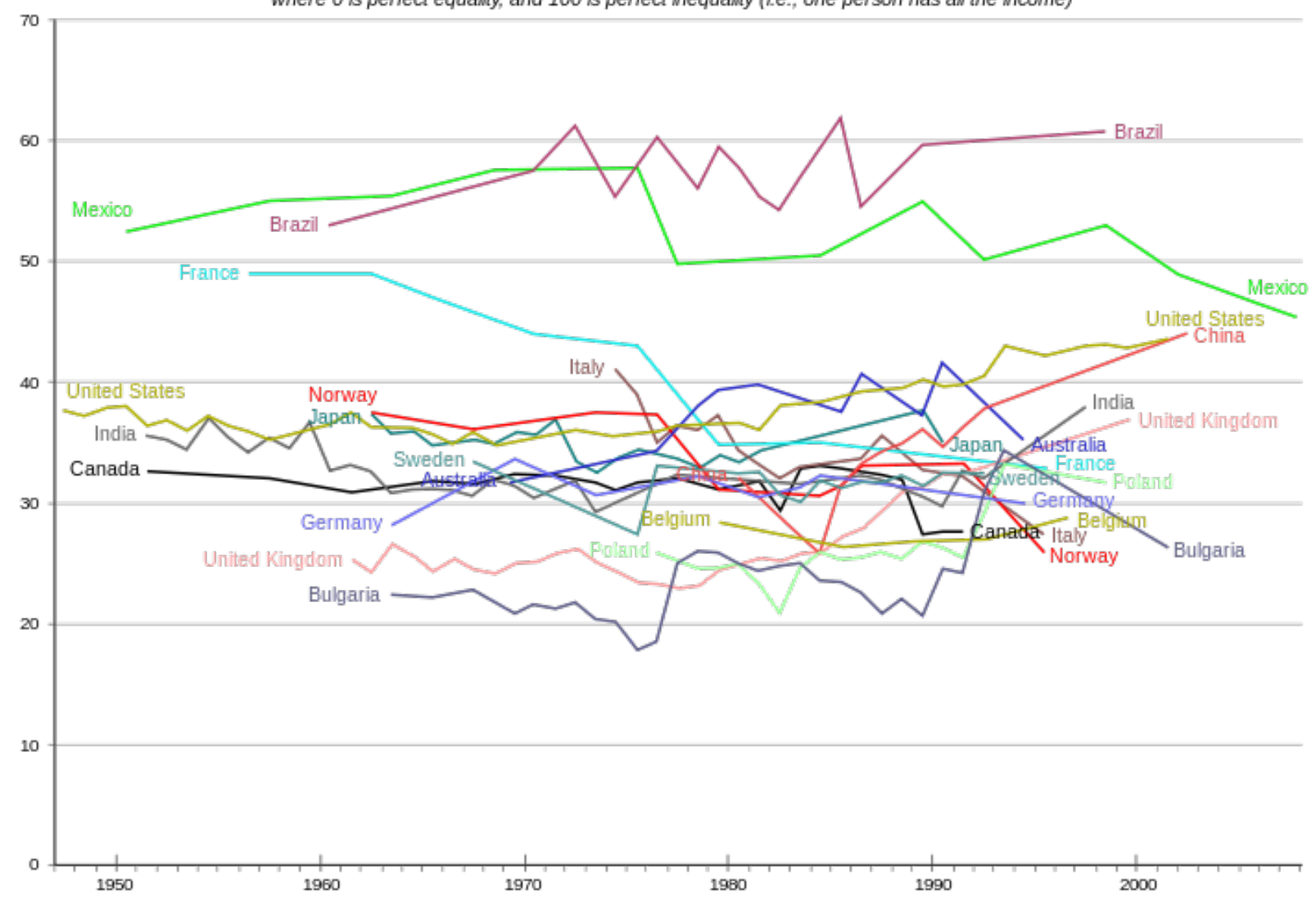


Table 2

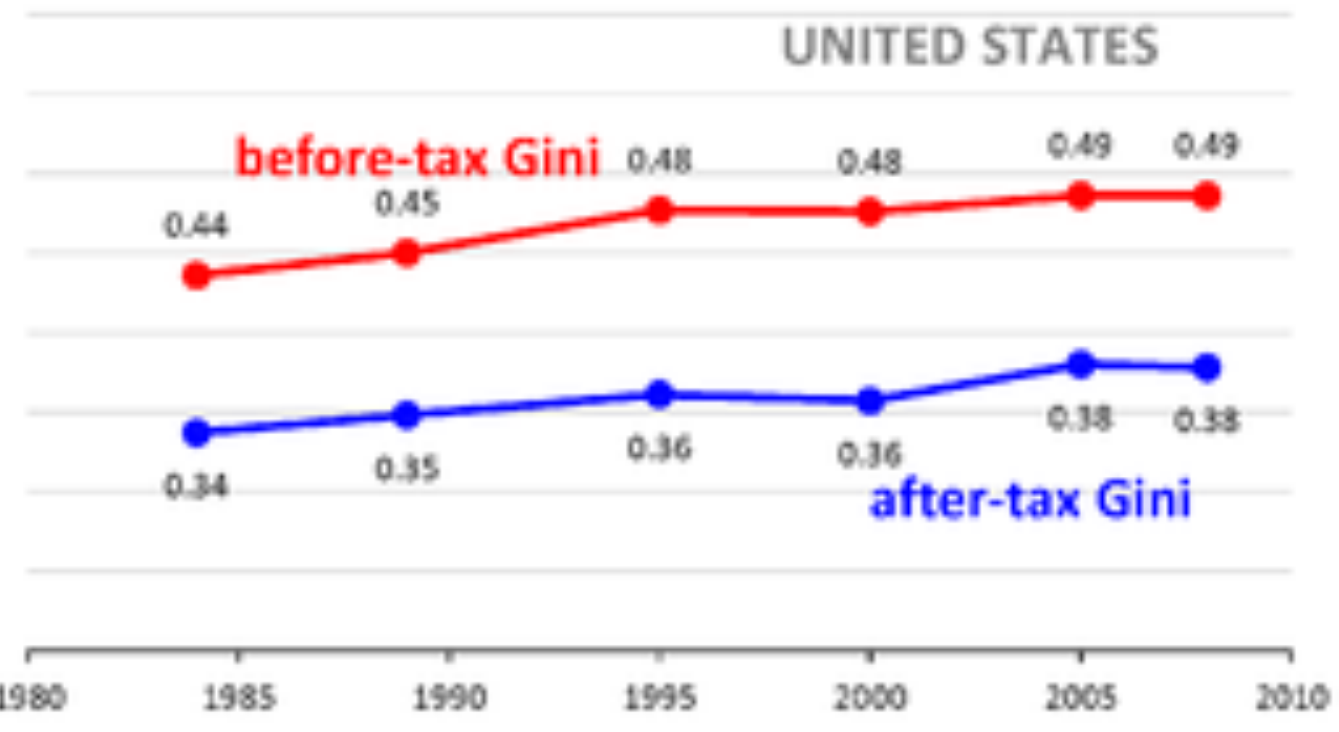


Law \& Economics W orking Papers, Art. 96 [2014]

Table 3 
Figure 12.

\section{Reduction in Income Inequality from Transfers and Federal Taxes}

(Percentage reduction in Gini index)

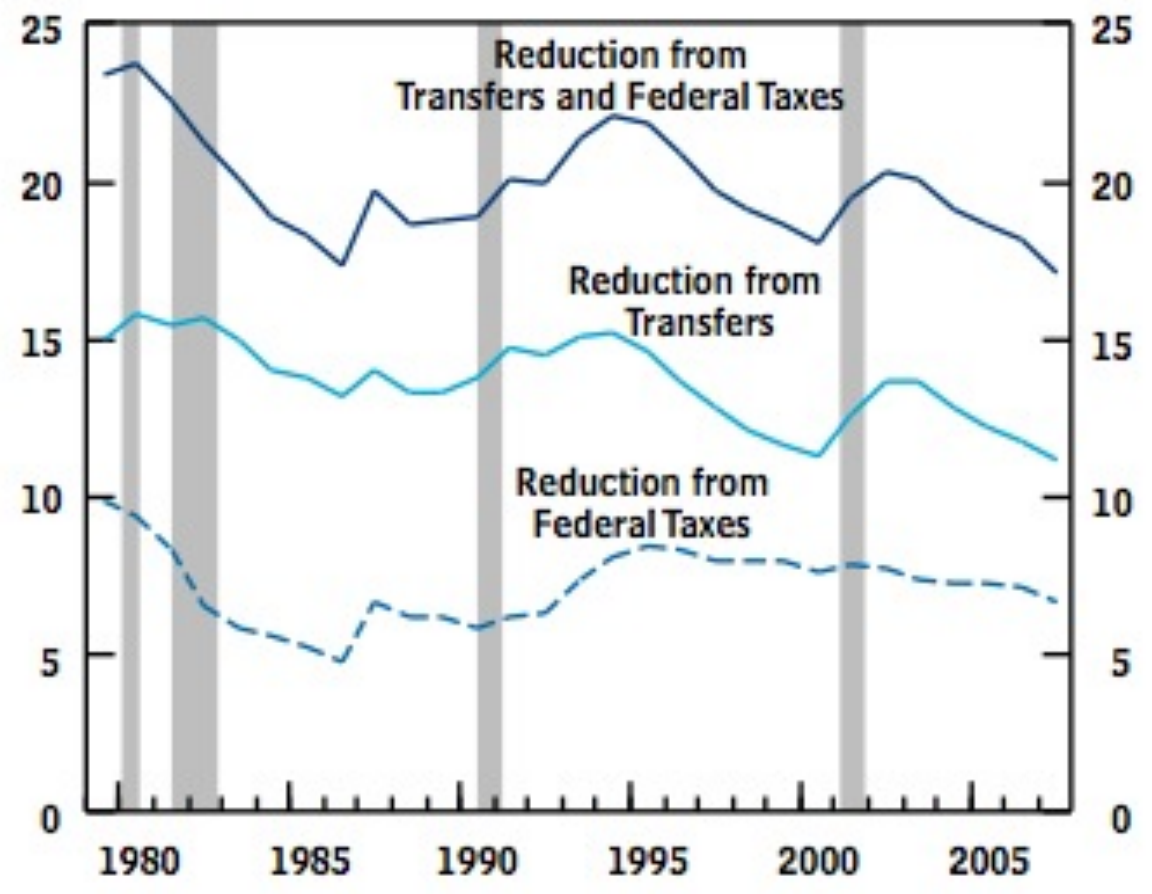




\section{REFERENCES}

Acemoglu and Robinson (2012). Acemoglu, D. and J. Robinson. Why Nations Fail: The Origins of Power, Prosperity and Poverty. New York: Random House, 2012.

Avi-Yonah, 2000. Avi-Yonah, R. "Globalization, Tax Competition, and the Fiscal Crisis of the Welfare State." Harvard Law Review 113 (2000): 1573-1654.

Avi-Yonah, 2010. Avi-Yonah, R. "Designing a Federal VAT: Summary and Recommendations." Tax Law Review 63 (2010): 285-295.

Avi-Yonah, 2012. Avi-Yonah, R. "And Yet it Moves: A Tax Paradigm for the 21st Century." U. of Michigan Law \& Econ Research Paper No. 12-008. Available at SSRN: http://ssrn.com/abstract $=2055160$ or http://dx.doi.org/10.2139/ssrn.2055160.

CBO (2011). Congressional Budget Office. The Distribution of Household Income and Federal Taxes. Washington, DC: CBO, 2011.

Collier, 2013. Collier, P. Exodus: How Migration is Changing our World. New York: Oxford University Press, 2013.

Frank, 2014. Frank, Robert. "The Vicious Cycle of Income Inequality." New York Times, January 11, 2014: 20.

IRS, 2013. Internal Revenue Service. Statistics of Income. Washington, DC: IRS, 2013.

OECD, 2010. Organization for Economic Cooperation and Development. Intergenerational Social Mobility in OECD Countries. Paris: OECD, 2010.

Warren and Tyagi, 2007. Warren, E., and A. Tyagi. The Two Income Trap: Why Middle-Class Parents are Going Broke. New York: Basic Books, 2007.

Zingales, 2012. Zingales, L. A Capitalism for the People: Recapturing the Lost Genius of American Prosperity. New York: Basic Books, 2012. 